T. R. Gordon

University of California, Davis

A. J. Storer and D. L. Wood

University of California, Berkeley

\title{
The Pitch Canker Epidemic in California
}

Native Monterey pine (Pinus radiata D. Don) forests are currently found at three disjunct locations in coastal California and on two islands off the coast of Mexico. The mainland forests comprise, in total, approximately 4,500 ha (11), whereas the two island populations are limited to 150 ha on Cedros Island and fewer than 400 trees on Guadalupe Island (28). Collectively, these populations are significant ecological and recreational resources, but they are also a valuable repository of useful genetic traits for improved varieties of Monterey pine, which are widely used by the timber industry. In California, Monterey pine is important as a landscape tree, with an estimated 50 million standing trees as of 1985 . Monterey pines were especially popular for plantings on freeway rights-of-way, where they served as visual and sound barriers for the adjacent properties. It was among such trees that a dieback problem became apparent in Santa Cruz County (Fig. 1) during the mid-1980s.

In 1986, A. H. McCain, extension plant pathologist at University of California Berkeley, established that the affected trees were suffering from pitch canker (30), caused by Fusarium circinatum Nirenberg \& O'Donnell (=Fusarium subglutinans (Wollenweb. \& Reinking) Nelson, Toussoun, \& Marasas f. sp. pini). Subsequent surveys showed the disease to be widespread in coastal Santa Cruz County, with a clearly disjunct infestation being found farther inland, in Alameda County (Fig. 1). Curiously, the disease was also found in Christmas tree farms in Los Angeles and San Diego counties, more than $450 \mathrm{~km}$ to the southeast (8).

\section{Historical Development of Pitch Canker in California}

Pitch canker was first described in the southeastern United States (SE U.S.) in

Dr. Gordon's address is: Department of Plant Pathology, University of California, Davis 95616; E-mail: trgordon@ucdavis.edu

Publication no. D-2001-0918-01F

(C) 2001 The American Phytopathological Society
1946 (23), where it remains a chronic problem in plantations and seed orchards (13). At the time of its discovery in California, it was natural to suspect that $F$. circinatum was somehow transported to California from the SE U.S. A comparative study of the two regions revealed very limited diversity in the California population of the pitch canker pathogen, consistent with the view that it was a recent in- troduction (7). Much greater diversity was found in a sample of the pathogen population from Florida, which was selected to represent the SE U.S., in part, because of the generous assistance offered by G. Blakeslee at the University of Florida.

This assessment of the California and Florida populations was initially based on vegetative compatibility among the collected isolates (7). Isolates sharing com-

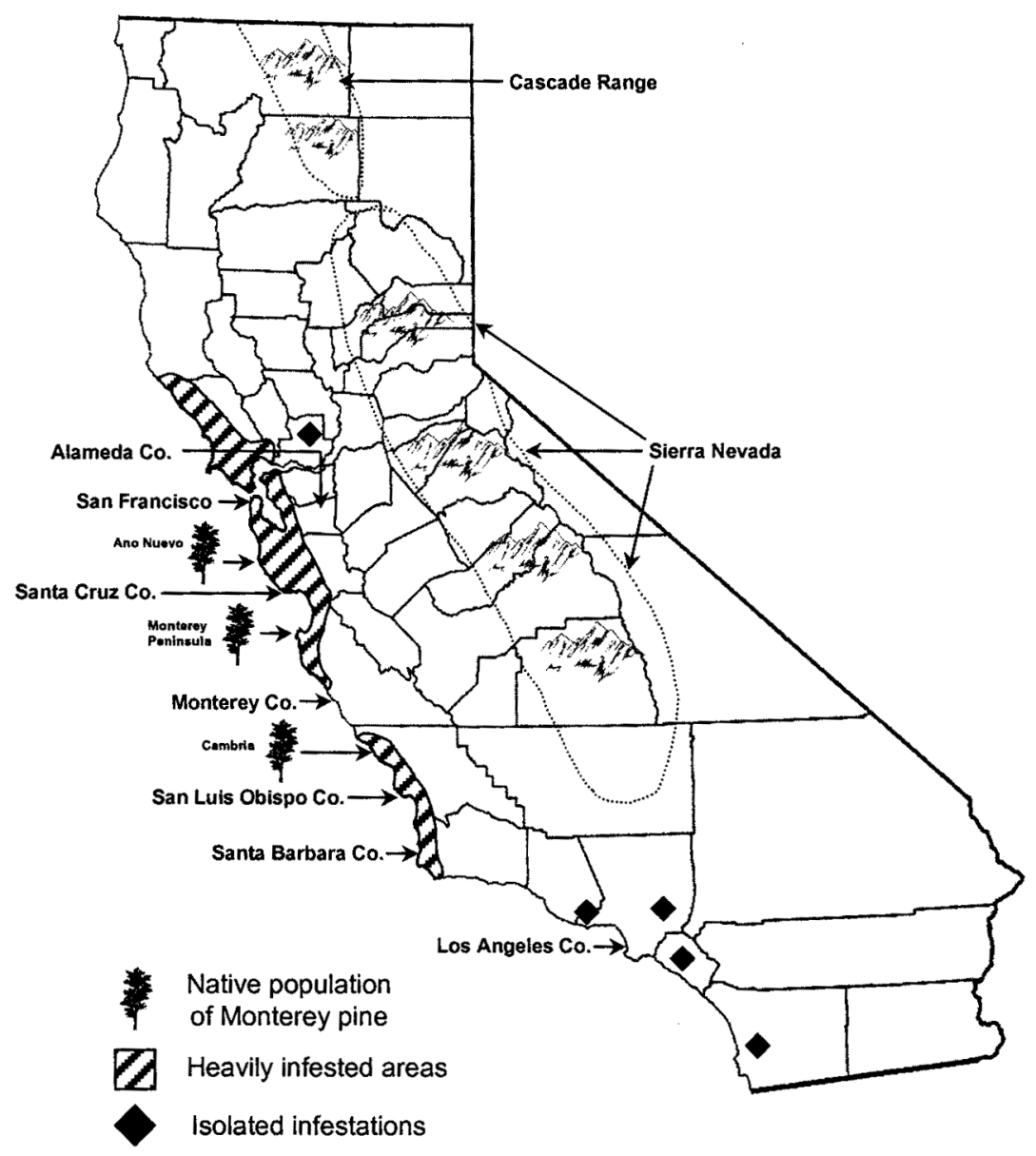

Fig. 1. Current distribution of pitch canker in California. The native populations of Monterey pine are within the heavily infested areas, which also include at least one native stand of bishop pine (Monterey Peninsula). Outside of the native stands, most of the pitch canker-affected trees are planted Monterey pines, but other pine species are also affected to a lesser extent. Most of the isolated infestations are Christmas tree farms. The dotted lines enclose areas that approximate the locations of the Sierra Nevada and Cascade Range. 
mon alleles at all loci that influence this trait (typically eight or more) will be vegetatively (or somatically) compatible, and are said to be associated with the same vegetative compatibility group (VCG). Isolates that differ at one or more of these loci will be incompatible. Consequently, the number of distinct VCGs in a sample provides one measure of diversity within the sampled population.

None of the isolates from Florida, or elsewhere in the SE U.S., was vegetatively compatible with any isolates from California (7). Whereas this result did not support a SE U.S. origin for the isolate(s) that initiated the California infestation, neither did it militate strongly against this hypothesis.

A lack of vegetative compatibility between isolates from different regions could reflect inadequate sampling of one or both populations. This would more likely apply to the Florida population of $F$. circinatum, where 45 VCGs were identified among 117 isolates examined (7). Thus, Florida isolates associated with a VCG also found in California may have simply escaped detection due to insufficient sampling. Of course, the high level of diversity found in Florida might indicate that this was an outcrossing population. If so, a VCG would not necessarily have a consistent association with an individual strain or clonal lineage (27), and other methods would be required to evaluate the relationship between the two populations.

The perception of the pitch canker pathogen as an outcrossing species was strengthened by findings from South Africa, where the disease was discovered in 1990 (44). Field isolates of $F$. circinatum (teleomorph $=$ Gibberella circinata $)$ in South Africa were shown to be interfertile and were confirmed to constitute a distinct biological species (5). Thus it was reasonable to suspect that a population long in residence in Florida may engage in sexual reproduction. However, closer scrutiny of the Florida population using molecular markers told a different story. In particular, seven VCGs were shown to have identical haplotypes based on eight polymorphic molecular markers (46), suggesting that novel VCGs may arise by mechanisms other than recombination through outcrossing. This does not necessarily mean that sexual reproduction is absent in the Florida population, only that one need not invoke this mechanism to explain the high level of VCG diversity that has been observed there.

As a practical matter, the fact that molecular haplotypes revealed far less diversity than did VCGs made it more likely that the former would detect genotypes common to the two populations. In fact this was the case, with identical molecular haplotypes being found both in Florida and California (46). This may indicate that a clonally propagating lineage, well established in the SE U.S., was introduced to
California and initiated the epidemic that is currently in progress.

Since the discovery of pitch canker in California, it has become apparent that this disease is also found in Mexico, where it occurs in native forests as well as in plantations (21). Although recognized only recently in Mexico, it is possible that pitch canker has been of long residence there. Given that Mexico represents a center of diversification of the pine genus $(32,34)$, one might even speculate that the pitch canker pathosystem originated in this area. Consistent with this interpretation was the finding that the Mexican population of $F$. circinatum had, by some measures, a higher level of genetic diversity than populations in any of the other regions examined (46).

Another hint of a Mexican origin for the pitch canker pathogen comes from the recent discovery of interfertility between $F$. circinatum (also referred to as G. fujikuroi mating population $\mathrm{H}[5])$ and $F$. subglutinans (G. fujikuroi mating population E) isolated from teosinte (Zea mays subsp. mexicana - the progenitor of corn) in Guatemala and southern Mexico (12). F. subglutinans was found to be intimately associated with seed in teosinte and thus may be an endophyte, as this species is known to be in corn. A successful cross, confirmed by demonstrating recombination of the alleles affecting vegetative compatibility, has been documented with only one pair of isolates, with other combinations proving to be infertile (12). Furthermore DNA sequences from conserved regions show the isolates originating from teosinte clearly to be associated with mating population $\mathrm{E}$, and not mating population $\mathrm{H}$. Thus we consider the cross to be a hybridization event between otherwise distinct biological species. Their ability to cross

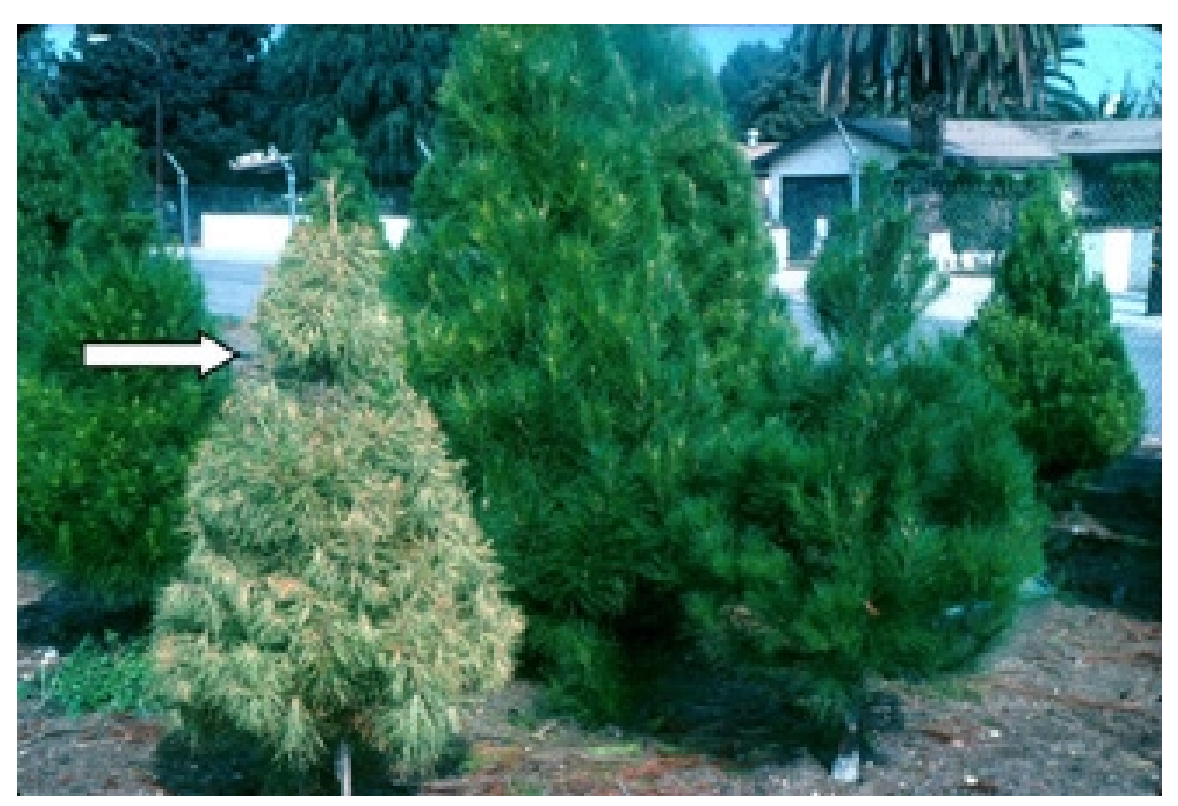

Fig. 2. A Monterey pine (arrow) with chlorotic needles, which are the typical symptoms of a pitch canker infection that has girdled the trunk of a tree near the soil line. Adjacent trees are healthy.

suggests a close relationship between the two species, which may reflect a common origin, and in any case, provides further support to the view that the pitch canker pathogen has a long history in southern Mexico.

If this interpretation is correct, the occurrence of pitch canker in the SE U.S. must trace its origin, directly or indirectly, to Mexico, although we have no data to document this connection. However, because a clonal lineage is common to the Florida and California populations, we presume the SE U.S., rather than Mexico, was the proximate source of the infestation now found in California. On the other hand, there appears to be a more direct connection between the $F$. circinatum populations in Mexico and South Africa (46), and we suspect that the disease may have reached South Africa as infested pine seed from Mexico as proposed by Wingfield et al. (48).

The ability of $F$. circinatum to survive in and on pine seed is well known $(1,37)$, and seed seems a likely vehicle for the movement of pitch canker to California, perhaps originally to a seedling nursery. Such nurseries supply seedlings to farms, where Monterey pine is the preferred species for local production of Christmas trees; as noted above, pitch canker was documented to occur in Southern California Christmas tree farms soon after its discovery in the state. The affected trees, 2- to 3-year-old Monterey pines, sustained infections at or below the soil line, which ultimately girdled the trunk and caused needles on the entire tree to become chlorotic and die (Fig. 2). Presumably, death of younger seedlings occurred as well, but symptoms at this growth stage are not distinctive and could easily have been dismissed as damp- 
ing-off caused by any of several resident fungi. For that matter, to the uninitiated, symptoms on the older trees might resemble root rot caused by Phytophthora spp. Thus, the pitch canker problem may have remained cryptic for many years after the pathogen was introduced to a seedling nursery.

The availability of infected but presymptomatic trees at a "choose and cut" Christmas tree farm provided an ideal opportunity to move the pathogen to other locations in California. The distribution of
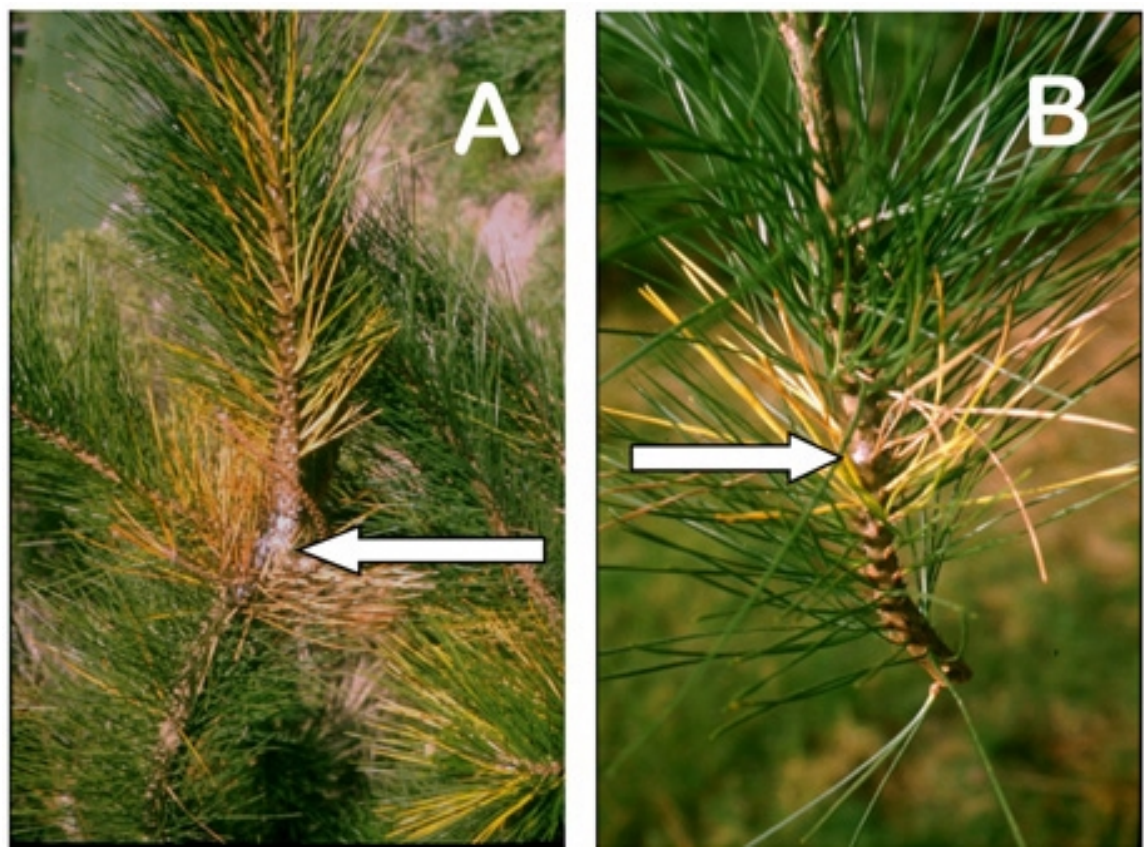

Fig. 3. Early symptoms of pitch canker on Monterey pine. The site of infection is indicated by the accumulation of resin (arrow), which may occur at branch whorls, A, or between whorls, B, and by chlorotic needles close to the infection site. Eventually all needles distal to the infection will become chlorotic and die. The fascicles typically abscise quickly, leaving a bare stem.
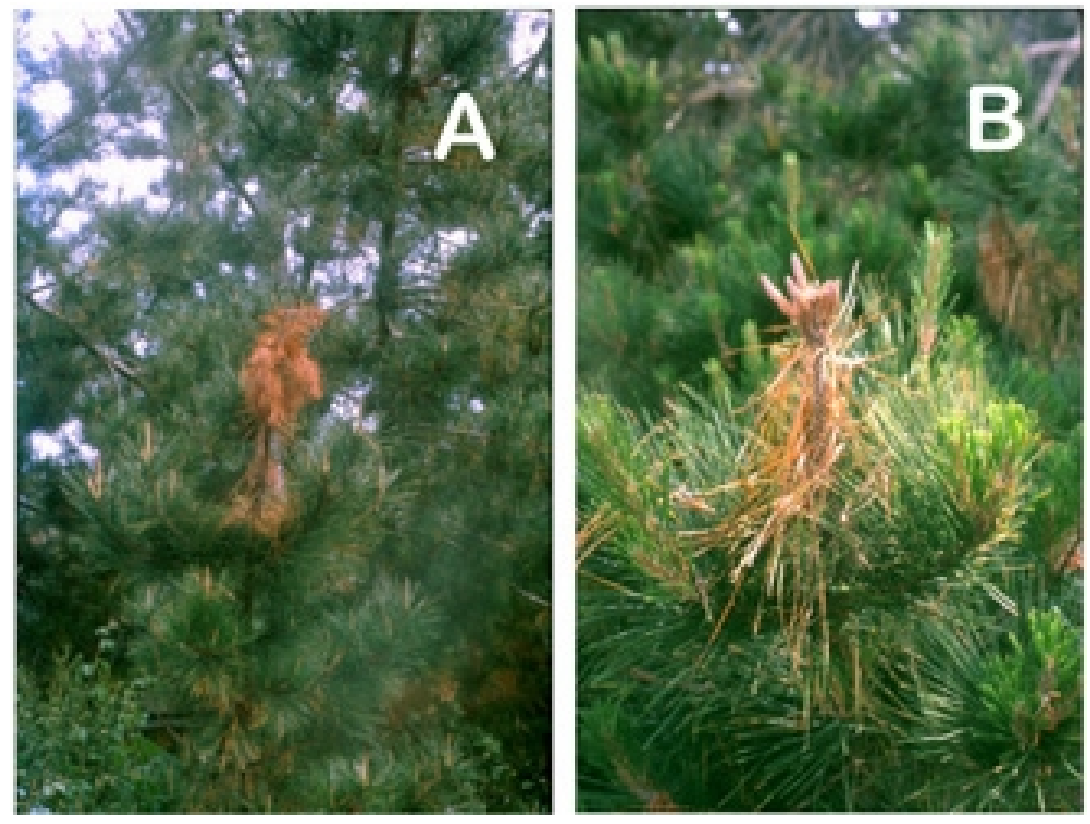

Fig. 4. A dead branch tip, in the canopy of a large tree, A, and at the top of a smaller tree, $B$, resulting from a girdling lesion proximal to the symptomatic needles. seedlings from a known infested site in Los Angeles County to a Christmas tree farm in Santa Barbara County (Fig. 1), where VCG C3 also was found.

It was not until a later survey was conducted that we became aware of a much larger infestation north of Santa Barbara, in San Luis Obispo County, which included the native stand at Cambria (Fig. 1) (17). Anecdotal evidence indicates that pitch canker, although not initially recognized as such, was probably in San Luis Obispo County at least as early as 1988. The pathogen population throughout this region was dominated by VCG C3 (17); the only co-occurring VCG, C8, was recovered at a low frequency and in a very limited area (17).

Taken together, these facts are consistent with the establishment of pitch canker in a pine nursery and its subsequent dispersal on infected but symptomless planting stock. After its arrival in a new area, the pathogen could have been further disseminated by insects colonizing the trees following their death, and possibly also as wind-borne propagules (8). Once pitch canker had killed large trees, their removal and disposal (often as logs for firewood) offered additional opportunities for the pathogen to spread. As pitch canker has become more widely established in California, the multitude of inoculum sources and means by which they can be moved has probably greatly reduced the relative importance of nursery stock and Christmas trees as vehicles for dissemination of the pathogen.

\section{Dynamics of Disease Development in California}

Notwithstanding the problems caused by pitch canker in the production of Monterey pines as Christmas trees, by far the most significant impact of the disease in California has been the damage done to adolescent and mature Monterey pines in landscape plantings and more recently in native forests. Typically, the first symptom of pitch canker on these larger trees is branch dieback. This results from a lesion, usually within one or two whorls of a branch tip (Fig. 3), that girdles and kills the affected branch distal to the point of infection (Fig. 4). In most cases, axial growth of the pathogen does not extend very far proximally, and so does no further visible damage to the tree. The disease intensifies through repeated infections that can lead to extensive dieback in the canopy (Fig. 5) Infections may eventually include larger diameter branches and the main stem (trunk) of the tree; such infections are often made conspicuous by extensive production of resin (Fig. 6). In some cases, diseased trees are severely weakened and may suffer top kill due to girdling of the trunk and/or attack by engraver beetles (Fig. 7); cankers lower on the trunk often result in death of the entire tree (15). 
This sequence of events has been documented by monitoring the development of pitch canker in plots of Monterey pine over a 4-year period (40). These plots were established in urban plantings of Monterey pine in 1992 and yielded a number of insights into the dynamics of pitch canker under California conditions. First, nearly all trees

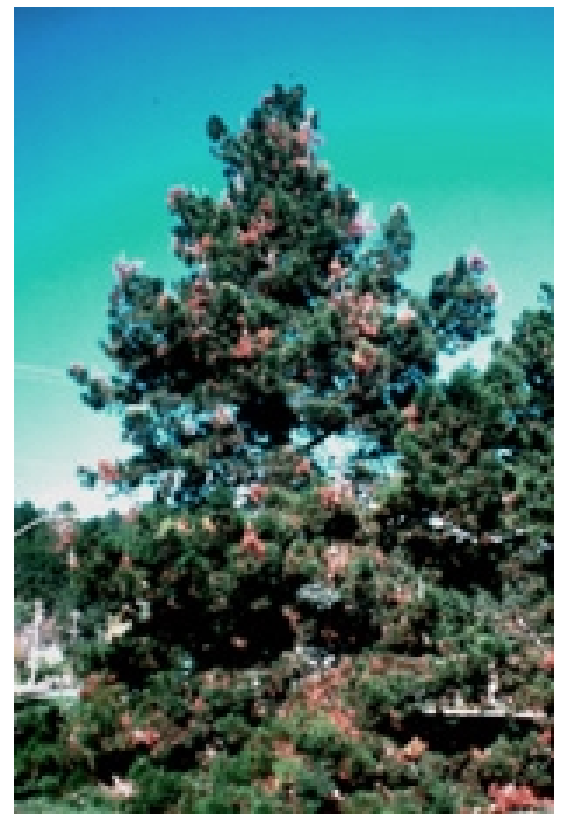

Fig. 5. A Monterey pine tree with extensive canopy dieback resulting from multiple branch tip infections. (Picture provided by Jack Marshall, California Department of Forestry and Fire Protection)

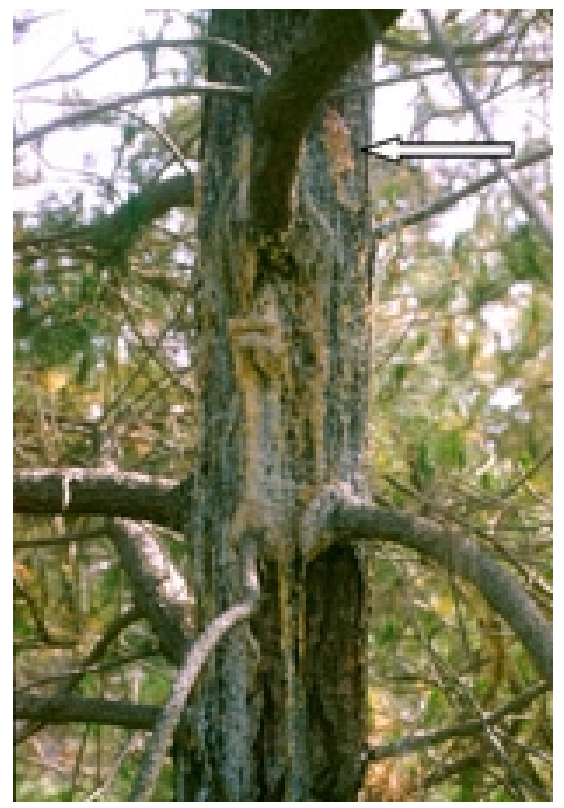

Fig. 6. Resin streaming on a Monterey pine tree with infections on the main stem (trunk) of the tree. Nearly all of the visible resin is attributable to pitch canker, but the small resin mass indicated by the arrow is the result of colonization by pitch moth and is not diagnostic of pitch canker.
(98\%) eventually sustained at least one infection, with the remaining $2 \%$ of trees being free of symptoms throughout the 4year observation period (40). An additional $7 \%$ never sustained more than two branch tip infections. The differential development of symptoms was probably a reflection of relative susceptibility to pitch canker. This interpretation is supported by earlier findings that disease-free trees in otherwise heavily diseased stands showed a significantly slower rate of lesion development than the visibly susceptible trees, when inoculated artificially (8). Other studies have more fully characterized resistance to pitch canker in Monterey pine and will be described below.

Another important generality emerging from the urban plot studies was a tendency for many trees in a stand to sustain a few infections before any of them became severely diseased (40). This pattern was consistent with the hypothesized role of insects as vectors that wound and thereby inoculate young branches more or less randomly. Thus, when most trees are disease free, there is a greater probability that a newly infected branch will be on one of these trees, rather than on an already infected tree. As more trees in a stand become diseased, the likelihood increases that new infections will occur on trees that already have at least one infection.

\section{Association of Insects with Pitch Canker Pathogen}

The role of insects as wounding agents and vectors appears to be a critical feature of the pitch canker pathosystem in California, in contrast to the SE U.S., where insects are accorded a comparatively minor role in the epidemiology of pitch canker. In the SE U.S., wounds associated with wind, hail, and other weather-related events, and with various silvicultural practices, are considered to be of primary importance as infection courts (13).

In California, four species of twig beetles (Pityophthorus spp. (Coleoptera:Scolytidae)) have been shown to carry $F$. circinatum $(9,25)$, and experimental evidence documents the ability of $P$. setosus Blackman to transmit pitch canker to small branches on Monterey pines (A. Storer and D. Wood, unpublished; T. Gordon and J. Sakamoto, unpublished). Similar documentation has been obtained for the vectoring activity of the cone beetle (Conophthorus radiatae Hopkins (Coleoptera:Scolytidae)), the deathwatch beetle (Ernobius punctulatus (LeConte) (Coleoptera:Anobiidae)) $(24,25)$, and the engraver beetle (Ips paraconfusus Lanier (Coleoptera:Scolytidae)) (15). Two other Ips species are known to carry the pitch canker pathogen and most likely also serve as vectors. Engraver beetles are presumed to be responsible for vectoring the pathogen to larger diameter branches and tree trunks, as this is the type of material in which they normally establish galleries. Finally, the spittlebug, Aphrophora canadensis Walley (Homoptera:Cercopidae), has been shown to act as a wounding agent capable of initiating infections in internodal regions on succulent shoots during the late winter and early spring (42). In aggregate, the above-cited studies provide strong support for the view that insect-mediated infections are a key element in the pitch canker disease cycle in California (Fig. 8). Such infections could be initiated by insect-borne inoculum, in which case the insect is truly a vector, or by inoculum already present on the branch surface, with the insect serving as a wounding agent. The relative importance of these alternative modes of infection is currently under study.

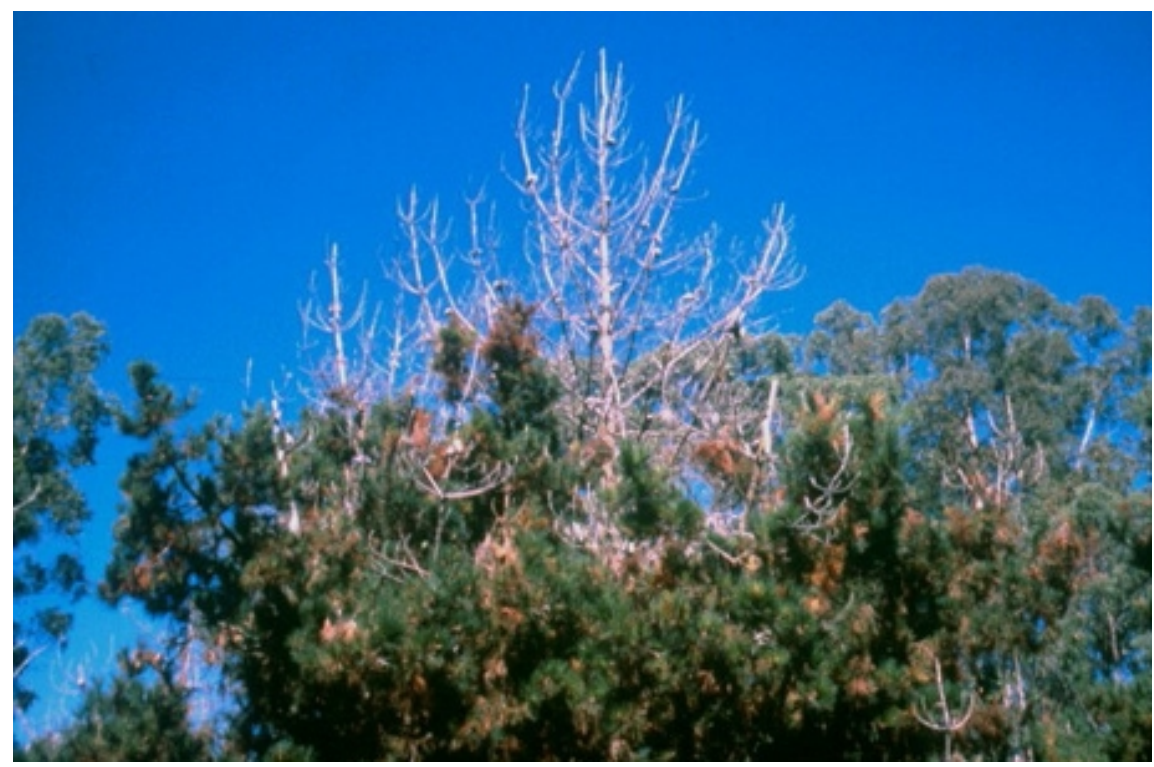

Fig. 7. Top-kill resulting from multiple pitch canker infections. Mass attack by engraver beetles (Ips spp.) often contributes to this syndrome. (Picture provided by Jack Marshall, California Department of Forestry and Fire Protection) 
Given that small branches are typically the first to show symptoms of pitch canker, Pityophthorus spp., which preferentially colonize branches in this size class, are presumed to be important in the establishment and early intensification of the disease. Although Leach's rules of proof (26) have been satisfied for $P$. setosus (25;
A. Storer and D. Wood, unpublished) and are likely applicable to three other twig beetle species, in one key respect their hypothesized vectoring activity appears

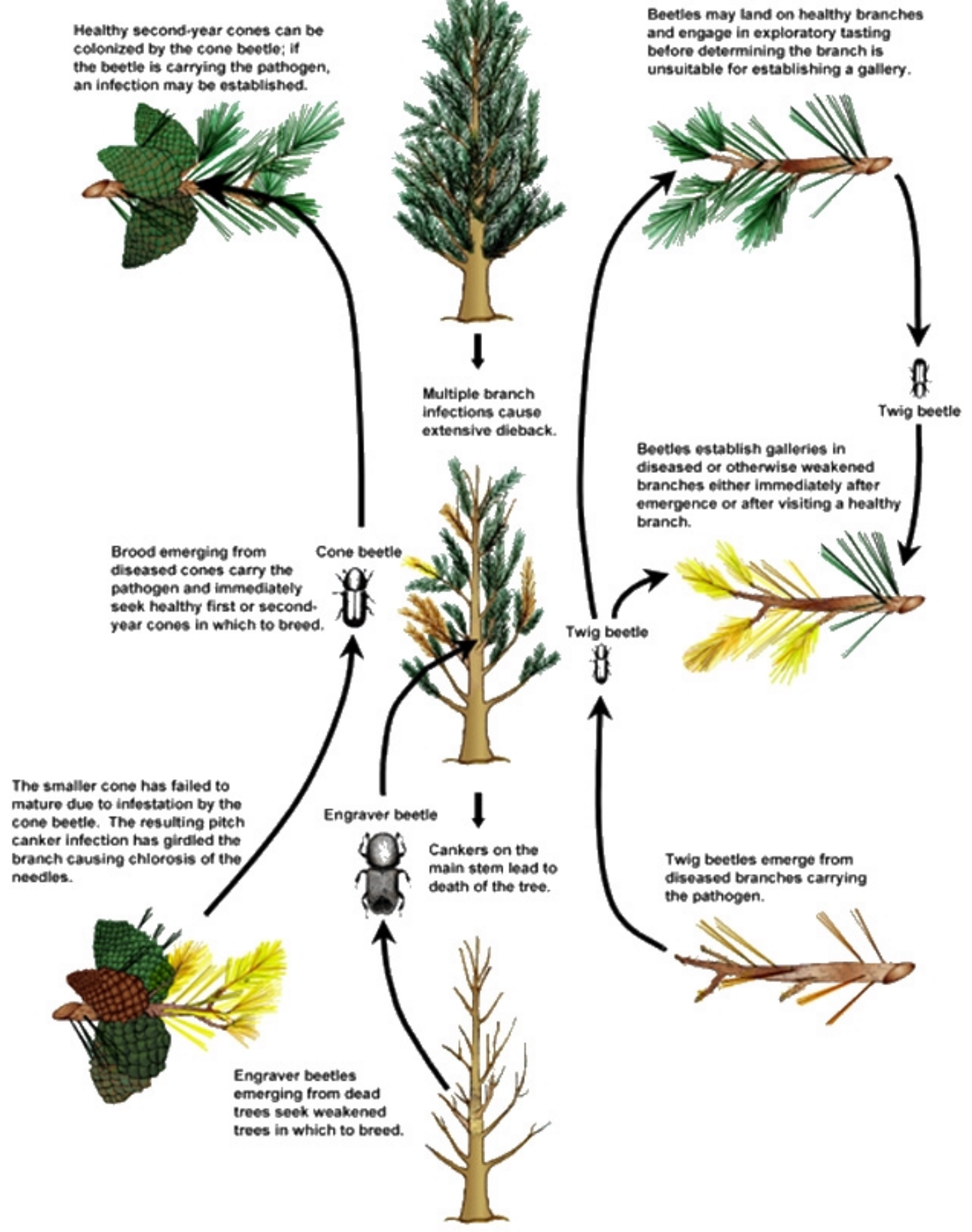

Fig. 8. Several of the insect-mediated infection pathways that collectively represent the principal means by which pitch canker infections are established on susceptible pines in California. The trees, shown in the center of the figure, represent the typical progression of pitch canker symptoms. Tip dieback is most commonly associated with wounding caused by twig beetles or cone beetles, as represented on the right and left sides of the figure, respectively. Infections on the larger branches and the main stem of the tree are associated with wounding caused by engraver beetles (bottom center of figure). 
inconsistent with their life histories as currently understood. A young adult twig beetle emerging from a gallery is not known to require feeding on healthy tissue to achieve reproductive maturity, but instead immediately seeks a weakened branch in which to breed. Thus, beetles emerging from a diseased branch may carry the pathogen, but if they have no requirement to feed on a healthy branch, where is the opportunity to transmit the disease?

Contrast this with the life histories of Scolytus scolytus Fabricus and S. multistriatus (Marsham) (Coleoptera:Scolytidae), which vector Dutch elm disease (16). These insects feed on the phloem in the axils of young shoots prior to seeking a weakened tree in which to breed. Thus, where a beetle establishes a gallery in a diseased tree, the brood are likely to emerge carrying the pathogen, and they will then feed on healthy trees, to which the disease can be transmitted. Pityophthorus spp., on the other hand, are not known to feed on healthy branches, eliminating the most obvious opportunity for transmission of the pathogen to a healthy tree. Typically, twig beetles breed in branches that have died recently or that are shadesuppressed and therefore less physiologically active than younger branches higher in the canopy (9). However, suppressed branches are rarely seen to develop symptoms of pitch canker. Rather it is young, actively growing branches that become infected (40), and these do not constitute suitable breeding sites for Pityophthorus spp.; hence the difficulty in explaining how twig beetles could be vectoring the pathogen to such branches.

To account for this anomaly, we hypothesized that twig beetles do not identify suitable substrates prior to landing, using either visual or olfactory cues. If so, then twig beetles may land on branches more or less randomly and thereafter engage in exploratory tasting and/or feeding in order to gauge the suitability of a branch for colonization. If the branch is physiologically active, exploration would probably be limited to tasting and the beetle would depart to continue its search, but wounding that resulted from tasting might be sufficient to inoculate the branch.

Two lines of evidence support this view of twig beetle biology. First, experiments conducted in areas where twig beetle populations were high showed they were not attracted to host volatiles produced by cut branches (3), suggesting that Pityophthorus spp. cannot use these chemicals as cues to target weakened branches prior to landing. Second, experiments conducted under controlled conditions confirmed that $P$. setosus could induce wounding sufficient to cause pitch canker infections on healthy branches of Monterey pine. In these experiments, branches were sprayed with an aqueous spore suspension and allowed to dry prior to their exposure to twig beetles. Trees onto which twig beetles were released developed infections, whereas trees sprayed with inoculum but not exposed to insects did not (J. Sakamoto and T. Gordon, unpublished). Because inoculum was already present on the branch, it was only necessary for the twig beetles to create suitable wounds and not to act as vectors (i.e., to transport the inoculum). This procedure was adopted because the insects used were obtained from pheromone-baited traps, and only a low percentage of such insects would be expected to carry $F$. circinatum (9). We have not confirmed that the behavior of $P$. setosus we observed under controlled conditions also occurs in nature, but branches baited with a pheromone specific for $P$. setosus (10) did sustain very small puncture wounds that were not seen on the unbaited controls (A. Storer and D. Wood, unpublished). These wounds may have resulted from exploratory tasting by P. setosus.

If, as it appears, wounds created by Pityophthorus spp. are very superficial, the fungus may require an external source of moisture in order to establish an infection. In the experiments described above, where infections were associated with exposure to $P$. setosus under controlled conditions, trees were maintained at $100 \%$ relative humidity for $24 \mathrm{~h}$ following removal of the insects. Whether or not lower ambient humidity would allow infections to occur is currently under investigation. Possible implications of such environmental limitations on the eventual distribution of pitch canker in the western United States are discussed below.

\section{Differential Susceptibility to Pitch Canker in Monterey Pine}

Pitch canker has long been known to have a wide host range, and early work by Hepting (22) showed that Monterey pine was among the species that were susceptible, based on artificial inoculations. Indeed, Monterey pine proved to be highly susceptible under field conditions, and this, coupled with its popularity as a landscape tree, was an essential element in the development of the pitch canker epidemic in California. Dense and nearly continuous plantings of Monterey pine provided a host bridge from the initial infestations into native stands of this species to the south, on the Monterey Peninsula, and to the north at Año Nuevo (Fig. 1). The progression of the disease in these and other coastal regions of the state thus appeared to be limited only by the availability of susceptible host trees. Data from our monitoring plots (discussed above) might suggest therefore that as few as $9 \%$ of standing trees would survive and fewer still would escape damage entirely. Such a projection now appears unduly pessimistic for reasons that will be detailed below.

If initial estimates of susceptibility were extrapolated to a similar level of mortality, it certainly constituted a disaster for landowners who would not only suffer the aesthetic and economic damage of losing mature landscape trees, but would also bear the costs of removing hazardous trees. On the other hand, even if only $2 \%$ of the host population proved to be resistant, it could allow for long-term management of the problem, provided the resistance proved to be heritable and durable. Consequently, work was undertaken to document that resistance was a consistent attribute of individual trees and not an artifact of the circumstances under which these trees were growing.

The first step in the characterization of resistance to pitch canker was the development of an artificial inoculation procedure that would provide a meaningful measure of susceptibility. In the procedure we adopted, an aqueous spore suspension is deposited in a small wound made in a young branch. Sometime thereafter, typically 30 days in a greenhouse, the bark is pared away from the inoculation site and the length of the lesion is measured. We used this method to screen vegetatively propagated clones of Monterey pine (19) as well as exotic pine species that constituted alternative landscape trees in some areas (18).

Based on lesion length at the site of inoculation, a ranking of Monterey pine genotypes was shown to be consistent over time and to be independent of the location where the experiment was conducted (19). In addition, all the $F$. circinatum strains known to occur in California were tested, and they did not interact differentially with host genotypes (19). Statistically significant differences in virulence among California strains were observed, but these differences were relatively small in magnitude. At a field site where pitch canker was prevalent, trees judged to be resistant, based on artificial inoculations, remained free of natural infections (19). As of 2001, these putatively resistant trees had been disease-free for 8 years. A related study confirmed the occurrence of resistant trees in a naturally regenerated native stand of Monterey pine on the Monterey Peninsula (36).

These results suggested that resistant selections could be used to reestablish landscape plantings of Monterey pines in areas where pitch canker was a problem. In native forests, assuming heritability is sufficiently high, resistance should increase over time through natural selection in the presence of pitch canker. However, it is not yet known to what extent genetic resistance will be manifested in young seedlings. We do know that current-year succulent growth tends to be more susceptible than woody tissue on the same tree, and that, in some cases, juvenile tissue in rooted cuttings sustains greater lesion development than the mature tree from which 
it originated (T. Gordon, unpublished). Thus it is possible a genotype capable of developing into a resistant tree would, at the seedling stage, succumb to pitch canker.

If genetic resistance is to contribute to the management of pitch canker, it must remain effective for an extended period of time. In a native forest, survival to reproductive age (10 to 15 years) might be sufficient to sustain the species, but to be useful as landscape trees, resistant Monterey pines must survive for longer periods of time and sustain few enough infections to retain their aesthetic value. The durability of genetic resistance will be strongly influenced by the pathogen population. Variation that affects virulence could result from mutation, recombination due to outcrossing, or introduction of exotic strains. If a major gene contributes to host resistance, its effect might be negated by a single mutation in the pathogen. On the other hand, if resistance is determined by multiple genes, then any given mutation in the pathogen might affect resistance only incrementally. Of course sexual reproduction could greatly accelerate the rate at which more virulent genetic combinations are generated.

\section{Potential for the Pathogen to Overcome Genetic Resistance}

As already indicated, $F$. circinatum is capable of producing a sexual stage (teleomorph = Gibberella circinata,$=G$. fujikuroi mating population $\mathrm{H}$ ). The fungus is heterothallic, and both mating types are found in the California population (47). However, as yet there is no evidence to indicate that anything other than clonal propagation has occurred in nature. From a sample of over 900 isolates, collected over a period of 14 years, only nine VCGs have been identified $(7,17$; T. Gordon and S. Kirkpatrick, unpublished); three of the nine VCGs are unified by weak compatibility among some of their constituent isolates and might equally well be regarded as a single heterogeneous VCG (46). So, by this measure, diversity in the California population is low.

Although a low level of VCG diversity would be consistent with clonal propagation, it could also be explained by a limited potential to generate different VC genotypes. For example, if the two mating types differed at only three of the loci affecting vegetative compatibility, recombination could generate at most eight different combinations $\left(2^{n}\right.$, where $\left.n=3\right)$. By this logic, a low level of allelic diversity at VC loci could beget limited VCG diversity in the population. However, this is not the case in the California population, as 30 VCGs were identified among 152 progeny of a single cross between wild type strains ( $T$. Gordon and S. Kirkpatrick, unpublished). Only two VCGs identified among the progeny were known to occur naturally in the California population: VCG C4 (the same as one of the parents) and VCG C1. Thus if the California population were outcrossing, we would expect to find greater VCG diversity. One caveat to this conclusion is that some of the progeny were nearly avirulent, and thus might escape detection.

A separate line of evidence that is consistent with clonality in the California population of $F$. circinatum is a lack of variation within VCGs. Eight polymorphic molecular markers showed identical haplotypes for all isolates associated with the same VCG (46). If isolates sharing the same VC genotype were products of recent recombination, they would be associated with different genetic backgrounds. In this case it would be extremely unlikely that isolates associated with the same VCG would be identical with respect to eight other markers. On the other hand, this is exactly the pattern one would expect if all the isolates in question were clonally related.

Obviously it remains possible that recombination has occurred and that sampling has simply failed to detect recombinant progeny. It is also possible that reproduction is entirely clonal, but only because of limited overlap in the distributions of the opposite mating types of $F$. circinatum (47). Presumably this is an artifact of the manner in which the initial introductions were made, and over time continued movement of isolates by various means will lead to more general distributions of both mating types. This may increase the prospects for mating under field conditions in the future.

Although we cannot forecast the likelihood of outcrossing under natural conditions, we can anticipate, to some extent, how progeny of sexual reproduction might differ from the parental types with respect to virulence. In a laboratory cross of California strains, the progeny showed a wide range of variation in virulence (T. Gordon and S. Kirkpatrick, unpublished). Nearly all were intermediate relative to the two parental strains, and none was significantly more virulent than the most virulent of the two parents.

Our tests do not preclude the possibility that more virulent genotypes might result from a cross that occurs in nature. One way to evaluate the potential for such crosses to affect virulence over time is to characterize the heritability of virulence and the potential for directional selection to increase the mean virulence of the prevalent isolates. Such studies are currently in progress and may provide an indication of how the pitch canker pathogen will evolve over time. Although increases in virulence within the population could have negative consequences for susceptible hosts, if such changes are gradual, they might be offset to some extent by selection for enhanced resistance in the host population.
Changes in the California population of $F$. circinatum could occur very quickly by the introduction of strains from outside the state. Limited samplings of the populations in Florida, Mexico, and South Africa identified isolates that were virulent on cloned ramets of a Monterey pine genotype that was resistant to resident California strains (T. Gordon and S. Kirkpatrick, unpublished). The opportunities to import $F$. circinatum on various forms of host material are many. Recent examples include seed of longleaf pine from South Carolina used to establish a nursery planting in San Luis Obispo County, and pine needles from Georgia, brought in for use as a mulch in a new housing development in the Sierra Nevada (Fig. 1). F. circinatum was recovered from one of 50 longleaf pine seed tested, and this isolate was not vegetatively compatible with resident California strains (T. Gordon and S. Kirkpatrick, unpublished). Likewise, an isolate of $F$. circinatum obtained from the imported pine needles was not associated with any of the VCGs known to occur in California. In neither case did the importation violate any state regulations, so there is little prospect for preventing similar occurrences in the future.

\section{Induced Resistance and Disease Remission}

The relative abundance of resistant and susceptible Monterey pines in native forests will provide an indication of the extent to which this species will ultimately be affected by the pitch canker epidemic in California. However, we now know that initial measures of resistance to pitch canker are not entirely predictive of the damage individual trees will sustain from the disease. In particular, it has become apparent that susceptibility is not necessarily a static characteristic of a tree, but that it can change over time. The first clues to this phenomenon were progressive declines in lesion lengths on trees that were inoculated four times over a 2-year period (19), or three times over a 1-year period (36). These changes were suggestive of systemic induced resistance (SIR).

To test the hypothesis that exposure to the pathogen could enhance host resistance to a subsequent infection, we used trees established as clones from rooted cuttings and tested them under controlled environment conditions. This allowed us to compare identical genotypes in a common environment and thereby document a significant effect of prior inoculation on the lesion length that resulted from a subsequent challenge with the pathogen (2). This appears to be the first confirmed case of SIR in a coniferous tree.

Whereas the phenomenon of induced resistance is interesting in and of itself, it was not immediately clear that it had any significant implications for the course of the pitch canker epidemic in California. 
After all, thousands of infected trees had already died, so to the extent that their resistance was altered along the way, it did not prevent their ultimate demise. This picture changed dramatically when the urban plots that were originally established in 1992, and monitored through 1996 (40), were reevaluated in 1999.

The original motivation for revisiting the urban plots was to assess the amount of tree removal that had occurred during the 7 years since the plots were established. During the course of the data collection, it became clear that in areas considered to have severe pitch canker in 1992, some trees that had high levels of infection in 1992 were free of disease symptoms in 1999 (A. Storer, D. Wood, and T. Gordon unpublished). Old branch tip infections had broken from many of these trees, and subtending lateral branches continued to grow. Thus, branch stubs with growth of laterals around them were characteristic of an infection that had become inactive.

The highest levels of apparent disease remission were recorded at New Brighton State Beach (Santa Cruz County), where pitch canker was discovered in 1986; $30 \%$ of the trees remaining in our monitoring plot had indications of disease remission, or $17 \%$ of the original population in this plot. In areas where pitch canker became established more recently, smaller percentages of trees showed signs of remission (A. Storer, D. Wood, and T. Gordon, unpublished). The proportion of trees capable of expressing disease remission may be higher than our data suggest because many trees were removed prior to their death. We do not know how many of these may have expressed remission had they been retained in the landscape.

The observed disease remission may be due to SIR, such as we have documented in Monterey pine under experimental conditions (2). However, it is also possible the activity of insect vectors in these areas had decreased, and therefore that new infections were not being initiated on diseasefree trees. Empirical measures of tree susceptibilities and levels of insect activity are needed to establish the relative importance of these factors. Whatever the explanation, the remission phenomenon argues for a conservative approach to tree removal. Consequently, our recommendations have been modified to the effect that diseased trees should not be removed until deemed necessary based on other criteria, such as safety or aesthetic considerations, to allow for the possibility that trees may go into remission. Thus the cost of tree removal and replacement may at least be delayed, if not avoided entirely. Of course, we do not yet know how persistent the remission effect will prove to be.

\section{Ecological Limitations on Pitch Canker in California}

The epidemic of pitch canker in California demonstrates that the environment in central and southern coastal California is generally conducive to disease development. Within this area, most of the damage to date has been associated with Monterey pine, but many other native California species are at least as susceptible, based on greenhouse inoculations (Table 1). Natural infections are evident as well on some of those species found in proximity to the existing infestations. Noteworthy in this respect are coastal stands of the other closed cone pines, knobcone pine $(P$. attenuata) and bishop pine ( $P$. muricata), many of which now have a high incidence of infection (A. Storer, T. Gordon, and D. Wood, unpublished observations). Both species have much more extensive native ranges than Monterey pine, and although bishop pine is restricted to the coast, knobcone pine is also found farther inland, in the Sierra Nevada (29).

Other pine species known to be susceptible, based on greenhouse tests, are rare or absent in the coastal forests where pitch canker is found, so it has not been possible to accurately gauge their relative susceptibility to natural infections (Table 1). This includes ponderosa pine ( $P$. ponderosa), gray pine ( $P$. sabiniana), and shore pine $(P$. contorta subsp. contorta). Studies of other pine species indicate that greenhouse tests are highly predictive of disease incidence in the field (18), suggesting that once the abovementioned native pines receive sufficient exposure to the pathogen, they will suffer the effects of pitch canker to the extent that Monterey pine and others have. If this proves to be the case, the distribution of gray pine, which rings the Central Valley of California (20), will offer an ideal infection pathway from the coastal forests to the Sierra Nevada and southern Cascade Range (Fig. 1), where extensive coniferous forests are found. In a similar fashion, shore pine and bishop pine could facilitate expansion of the pitch canker

Table 1. Susceptibility of pines grown in California to pitch canker, caused by Fusarium circinatum

\begin{tabular}{|c|c|c|c|c|c|}
\hline \multirow[b]{2}{*}{ Species } & \multirow[b]{2}{*}{ Common name } & \multirow[b]{2}{*}{ Status $^{b}$} & \multicolumn{2}{|c|}{ Susceptibility $^{\mathbf{a}}$} & \multirow[b]{2}{*}{ Reference } \\
\hline & & & Greenhouse & Field & \\
\hline Pinus attenuata & Knobcone pine & Native & $S$ & $S$ & 6,17 \\
\hline P. canariensis & Canary Island pine & Exotic & $\mathrm{R}$ & $\mathrm{R}$ & 18 \\
\hline P. contorta subsp. contorta & Shore pine & Native & $\mathrm{S}$ & $\mathrm{S}$ & 6,17 \\
\hline P. coulteri & Coulter pine & Native & $\mathrm{S}$ & S- & 6 \\
\hline P. halepensis & Aleppo pine & Exotic & $\mathrm{S}$ & $\mathrm{S}$ & 18 \\
\hline P. jeffreyi & Jeffrey pine & Native & $\mathrm{S}$ & $\mathrm{N}$ & 6 \\
\hline P. lambertiana & Sugar pine & Native & $\mathrm{S}$ & $\mathrm{N}$ & 30 \\
\hline P. muricata & Bishop pine & Native & $\mathrm{S}$ & $\mathrm{S}$ & 6,17 \\
\hline P. pinea & Italian stone pine & Exotic & $\mathrm{R}$ & $\mathrm{R}$ & 18 \\
\hline P. ponderosa & Ponderosa pine & Native & $\mathrm{S}$ & S- & 6,17 \\
\hline$P$. radiata & Monterey pine & Native & $S$ & S & $18,19,40$ \\
\hline P. sabiniana & Gray pine & Native & $\mathrm{S}$ & S- & 6,17 \\
\hline P. thunbergiana & Japanese black pine & Exotic & $\mathrm{R}$ & $\mathrm{N}$ & 18 \\
\hline P. torreyana & Torrey pine & Native & NT & S- & 17 \\
\hline
\end{tabular}

${ }^{a}$ Greenhouse tests of susceptibility are based on the results of artificial inoculations; the procedure described in the text was used for all species except sugar pine, for which a different inoculation method was used (30). Species are rated as susceptible (S) if they sustained definite lesions at the site of inoculation, or resistant (R) if there was little or no lesion development; NT indicates a species that has not been tested. Field susceptibility is based on observations of natural infections. Species are rated as susceptible (S) if numerous trees are known to be infected and/or some trees have sustained severe damage from pitch canker (e.g., multiple branch infections leading to extensive dieback in the canopy). Species that have frequently been observed in otherwise infested areas and for which few or no trees are known to have sustained natural infections and none have been severely damaged by pitch canker are rated resistant (R); the level of resistance differs within this group. For species rated S-, one or more infected trees have been observed, but the number of observations is too limited to provide a meaningful estimate of their relative susceptibility. For a species rated N, no infected trees have been observed, but the occurrence of this species in proximity to natural inoculum is too infrequent to conclude that the lack of disease is indicative of resistance.

${ }^{b}$ Native species are found in native forests but may also be grown for timber in plantations (e.g., ponderosa pine) or as landscape trees (e.g., Monterey pine); the exotic species are planted in various parts of the state. 
infestation northward along the California coast and into Oregon. Also relevant in this regard is Douglas-fir (Pseudotsuga menziesii), the only species outside the pine genus that has been shown to be susceptible to pitch canker (38); Douglas-fir is widely distributed on the north coast and in the Sierra Nevada. The extent to which this species will be affected by pitch canker is unclear, but evidence available to date suggests that Douglas-fir is only moderately susceptible to pitch canker (6); more extensive testing is required to confirm this.

The availability of a suitable host is necessary but may not be sufficient for a disease to be manifest. In the case of pitch canker, as it occurs in the western United States, insect vectors (or wounding agents) also are important. However, based on published host records (4), it appears this will not impose a limitation to the infection of most native California pine species, because many insects known to vector pitch canker are reported from multiple pine hosts (38). Furthermore, many less obvious pathways involving parasites, predators, and other gallery associates of the known vectors may also serve to move F. circinatum between host species (9). Thus, one might conclude that pitch canker will eventually affect native pines throughout the extensive inland pine forests of California and perhaps Oregon, Washington, and Canada as well. Whether or not the disease progresses to this extent may depend on how environmental conditions affect disease establishment. Two factors that seem likely to be important in this respect are: the effect of atmospheric moisture on the infection process, and the temperature range for growth of the pathogen.

As noted above, wounding by twig beetles, which appears to be an important mechanism by which infections are established on young branches, is relatively superficial. This reflects the fact that physiologically active branches are not suitable for colonization by twig beetles, and hence the wounding they cause presumably results only from limited bark penetration. As a result, the infection court is unlikely to be deep enough to reach an adequate supply of water. For this reason, the pathogen may depend on external sources of moisture to establish an infection. Although we have yet to experimentally confirm a requirement for high ambient humidity, evidence from field studies suggests that such a limitation may be operative under natural conditions.

In 1996, we established plots in native Monterey pine forests on the Monterey Peninsula. The principal objective of this study was to test for an effect of landscape type on disease development. However, the distribution of plots allowed us to subdivide them into two geographic categories: coastal and inland. The results documented a significant effect of geography, with coastal plots having a higher mean disease severity than inland plots and a greater rate of disease increase over a 3-year period (45). It is noteworthy that this "coastal effect" is apparent over a relatively short distance, as many of the inland plots are little more than $1 \mathrm{~km}$ from the coast. Although the basis for the effect is not known, it is consistent with an influence of fog and the associated condensation, which occurs with greater frequency and duration near the coast, relative to more inland locations. If this is the basis of the differential effect we have observed, it may portend a significant environmental limitation on the establishment of pitch canker in drier areas farther inland.

On a regional scale, a coastal effect might also be inferred from the distribution of pitch canker in California (Fig. 1). Of course, this could be the result of greater development in areas where the pathogen was first introduced, but the longer the present distribution remains in place, the more compelling the argument it offers for an environmental limitation on pitch canker. Experimental studies now underway should provide a more complete picture of the extent to which atmospheric moisture affects the infection process mediated by twig beetles. However, such limitations may not apply to other vectors, such as the cone beetle, which can incite infections in the process of colonizing first- and secondyear cones (25). Because the cone beetle has the potential to carry the fungus deeply into the cone, infection may occur in the absence of free moisture on the cone surface. If so, the prospects for expansion of the pitch canker infestation to more inland locations may be strongly influenced by the distribution of the cone beetle, which is not yet well characterized.

The ultimate geographic limits for pitch canker in western North America may also be affected by temperature requirements for growth of the pathogen. In particular, $9^{\circ} \mathrm{C}$ appears to be near the lower limit for fungal growth in culture (31). A similar limitation on infection was observed on trees under growth chamber conditions (31). This lower limit for growth and infection should make it increasingly difficult for the pathogen to become established as it moves to more northerly latitudes and to higher elevations. In the eastern United States, pitch canker has not been reported north of Virginia (13).

Even if these potential environmental limitations on the disease are borne out, extensive inland-forested areas in California would offer suitable conditions for pitch canker during some parts of the year. For example, prevailing weather in the foothills of the Sierra Nevada would be permissive during parts of the spring and fall in most years. Consequently, introduction of the pathogen to these locations, as could occur through movement of firewood, seed, soil, or infected trees, might well allow pitch canker to become established.

\section{Altered Interactions Resulting from Pitch Canker}

What we know about pitch canker as a pathogen in native forests is limited to what we have learned from its fairly recent development in Monterey pine stands. Already it appears that the impact of pitch canker goes far beyond the direct effects on susceptible trees. Although there are likely to be many as yet unrecognized effects on animal and plant communities associated with Monterey pine, here we will consider only the insects associated with the pitch canker pathogen, for which we have some evidence as to how they have been affected.

Insects that function as primary decomposers in Monterey pine forests, such as twig beetles and deathwatch beetles, were once benign associates of Monterey pine but are now injurious because they vector the pitch canker pathogen. Hence their impact on Monterey pine has been altered from a neutral to a negative one. A similar story pertains for the cone beetle, which reduces reproduction by damaging seeds but generally does not cause branch tip mortality distal to the cone whorl. When pitch canker is present, however, the negative impact of these insects is increased because they vector the pathogen into cone whorls and thereby cause mortality of the branch tip distal to the colonized cone. Furthermore, in the absence of pitch canker, cone beetle activity did not significantly enhance the quantity of breeding substrate for twig beetles. In the presence of pitch canker, however, both the cone beetle-colonized cone and the branch tip distal to the infected cone whorl are rendered suitable for colonization by twig beetles (25). Hence the effect of cone beetle activity on twig beetles has been altered from neutral to positive (39).

Ordinarily, twig beetles do not weaken trees, because they rarely colonize branches that were not already shade suppressed. However, where they are acting as vectors of the pitch canker pathogen, twig beetles (and cone beetles) help to weaken trees. This benefits engraver beetles (Ips spp.), which preferentially attack such predisposed hosts $(14,38)$. Undoubtedly the population sizes of many of these insect species have increased in the presence of the pitch canker pathogen, and work is underway to quantify the magnitude of these changes and of the altered interactions among insects and between insects and their host trees.

\section{Prospects for Management}

As is generally the case with diseases of trees, we are without realistic therapeutic options for dealing with pitch canker. Fungicides with activity against the pathogen are available, so, in principle, trees could be protected from infection. Such chemical controls might be exploited under nursery conditions to prevent seedling disease caused by $F$. circinatum, but for larger 
trees, maintaining a sufficiently high concentration of the active ingredient on all susceptible surfaces would be problematic, even if cost were not a consideration. Similar constraints would apply to insecticidal treatments for control of insect vectors. Furthermore, because the insects involved are all native associates of California conifers that contribute to the decomposition of wood, any large-scale effort to reduce their numbers would be difficult to justify.

The early phases of pitch canker development are characterized by branch tip infections, which can be pruned out to effectively eliminate the disease, at least temporarily. Of course new infections can occur, and this is especially likely where many diseased trees are present. Consequently, removal of infected branches is unlikely to alter the course of disease, and this expectation is supported by results from several rounds of eradicative pruning in Monterey pine stands that were relatively distant from other diseased trees (T. Gordon and M. Schultz, unpublished).

At approximately 6-month intervals, all infected branches were removed from trees in selected stands in Santa Cruz and Monterey counties. At one location, 57 symptomatic branches were removed in the initial round of pruning in a stand comprised of 51 mature trees. Totals of 101, 69, 370, and 588 diseased branches were identified and removed 7, 14, 22, and 43 months later, respectively. At the beginning of the study, only four trees in the stand had symptoms of pitch canker, but by the final pruning date, 48 of the 51 trees were diseased. Similar results were obtained at three other locations. Although it is possible the development of pitch canker would have been more rapid in the absence of the pruning efforts, this approach was clearly not effective in eliminating the disease or even in reducing its incidence or severity. Moreover, given that the pruning operations required a lift truck and a crew of skilled tree climbers, the costs involved would probably preclude the application of such measures in most situations, even if there were reasonable prospects for success. However, where pruning restores the aesthetic value of a tree and therefore allows it to be retained in the landscape, costs might be repaid if the tree recovers and the expense of removal and replacement is thereby avoided.

Given the limited options for dealing with diseased trees, management of pitch canker must focus on efforts to minimize future damage. For landscape trees, this includes: (i) minimizing dissemination of the pathogen through proper handling of infected materials, and (ii) replacing diseased trees with nonsusceptible species or resistant selections.

Where pitch canker becomes established in Monterey pines or other highly susceptible species, tree removal may eventually follow, with the attendant problems of disposal. To the extent that this material is kept within already infested areas, opportunities for movement of the pathogen to new areas can be minimized. However, the volume of material often exceeds the capacity for local utilization, so procedures that can reduce or eliminate the pathogen and its vectors from branches and logs are being explored. In particular, chipping of branches has been shown to greatly reduce the size of resident insect populations (W. McNee, D. Wood, A. Storer, and T. Gordon, unpublished). However, pathogen survival is not greatly diminished by this procedure, so exposure of the chips to elevated temperatures, as by tarping or composting, is recommended. Recent studies using infested wood chips showed that temperatures as low as $50^{\circ} \mathrm{C}$ can quickly eliminate the pathogen if the material remains wet (T. Gordon and S. Kirkpatrick, unpublished)

Logs cut from diseased trees could serve to disseminate the pathogen, and although they could be rendered pathogen-free through heat treatments or fumigation (33), the costs are prohibitive. For this reason, we have conducted preliminary tests of fungicides registered for sap stain control, some of which show the potential to reduce or eliminate the pathogen on the surface of logs, whether debarked or intact. The use of such treatments would be entirely voluntary, however, as no laws are in place to require them.

Identifying suitable replacement trees in pitch canker-affected areas is not a problem in most situations. Only pines are at risk of severe disease, and even within the pine genus, several species are known to sustain little or no damage from pitch canker (Table 1). This includes Japanese black pine $(P$. thunbergiana), Italian stone pine $(P$. pinea), and Canary Island pine $(P . c a-$ nariensis), all of which are popular landscape trees in Mediterranean climates (18). However, the abovementioned pines would not necessarily be considered acceptable replacements for Monterey pine in communities that are within or adjacent to native stands of this species.

Two of the native populations of Monterey pine (Cambria and Monterey) are adjacent to extensive residential and commercial developments. At many of the forest-urban interfaces, native trees have been retained and/or Monterey pines have been planted in an attempt to maintain a semblance of the native plant community throughout the developed area; such areas have been referred to as "urban (or urbanized) forests." Replanting with species other than Monterey pine would be inconsistent with this objective, although it would be desirable from the standpoint of disease management. Genetically resistant Monterey pines would be an obvious choice under these circumstances. However, although many pitch canker-resistant trees have been identified and propagated vegetatively, there is as yet no commercial source for this material. Local efforts are underway to select and propagate resistant cuttings from parent trees of appropriate local origin, and this may ultimately be sufficient to meet the demand. However, because the long-term durability of genetic resistance can never be guaranteed, we recommend deployment of pitch canker resistant Monterey pines only where land managers conclude that the value of retaining this species exceeds the risk that their trees may eventually be damaged by pitch canker.

In native stands, management of pitch canker can best be achieved through practices that promote natural regeneration of the forest. Fire results in plentiful regeneration and would also have the benefit of eliminating inoculum associated with the litter layer and the soil surface. However, the proximity of human habitations and other safety considerations will make fire impractical in many areas. The ability of Monterey pine to colonize openings in the forest canopy will ensure regeneration in areas where gaps are created by any of various means, including pitch canker-induced mortality (41). Under these circumstances, selection in the presence of pitch canker should ultimately increase the frequency of resistant trees in the population.

Monterey pines are relatively shortlived, and many native stands are considered senescent due to the preponderance of trees near the end of their natural life span. Thus, the process of regeneration will be critical to maintaining a Monterey pine forest, irrespective of pitch canker (41). Consequently, it may not be necessary to treat pitch canker-affected stands any differently than those that are free of disease. However, if natural regeneration is insufficient, more direct intervention might be required.

Where natural regeneration fails, replanting might be required to retain a Monterey pine forest at that location. If heritability of resistance to pitch canker proves to be high, broadcasting seed from nearby resistant trees might be an acceptable means of obtaining a stand and increasing the frequency of resistance to pitch canker. If this approach is not successful, seedlings prescreened for resistance could be transplanted into the forest. Alternatively, vegetatively propagated cuttings could be used. The latter method has the appeal of allowing for rapid production of planting stock but naturally raises concerns about extensive deployment of any single genotype. Until more is known about the genetic basis for resistance, the best way to address this issue is to propagate from as many different parental trees as practicable. Whatever approach is adopted, reforestation efforts will need to be carefully considered in terms of genetic conservation, in 
order to avoid unduly reducing genetic diversity and/or degrading the integrity of locally adapted genotypes (35).

\section{A Global Perspective}

Most of what we know about pitch canker is based on studies of this disease in three areas: California, the SE U.S., and South Africa. The manifestation of pitch canker is very different in these three locations, but one commonality is the occurrence of disease in seedling nurseries. Although the extent of the problem may vary, the essential ability of the pathogen to infect and kill seedlings is apparently independent of the many factors that differentiate the areas where the disease has been studied. The seedborne nature of pitch canker, and the pathogen's ability to survive in soil and incite cryptic infections on seedlings (37), make nurseries ideal sites for establishment and subsequent dissemination of the disease to new areas. Consequently, where pitch canker does not yet occur, as in New Zealand, Chile, and Australia, which have a combined total of nearly 4 million hectares planted to $P$. $r a$ diata, nurseries should be a primary focus of efforts to exclude the pathogen.

In contrast to its prevalence in seedling nurseries, the aerial phase of pitch canker is conspicuous in California and the SE U.S. but essentially absent in South Africa. Thus, although the co-occurrence of the pathogen and a susceptible host appear sufficient for pitch canker to kill seedlings, other limitations may apply to branch infections. One might speculate that it is a lack of suitable wounding agents that has kept pitch canker from developing outside of nurseries in South Africa (48). Episodes of severe weather do occur in South Africa, and, for example, wind driven hail is associated with extensive damage caused by Sphaeropsis sapinea (43). If the weatherrelated injuries are prone to infection by $F$. circinatum, it may be only chance that has kept canopy dieback due to pitch canker from developing to a significant extent in South Africa. On the other hand, most of the insects likely to act as vectors or wounding agents are not found in South Africa, reflecting the fact that pines are not native to this part of the world. Continued exclusion of pine-associated insects should be considered a high priority.

In the long term, efforts to exclude the pitch canker pathogen and the insects that vector it may only delay the onset of the disease in areas where susceptible hosts are grown in a conducive climate. From this perspective, the incorporation of genetic resistance into elite germ plasm offers the best insurance against future damage from pitch canker to plantation forestry. To this end, studies to characterize the genetics of inheritance of resistance to pitch canker are of primary importance to the continued utilization of $P$. radiata in pulp and lumber production worldwide.

\section{Acknowledgments}

The research on which this manuscript is based was supported, in part, by grants from the California Department of Forestry and Fire Protection, the California Department of Transportation, the Del Monte Forest Foundation, the Elvinia Slosson Endowment, Pebble Beach Company, the University of California Division of Agriculture and Natural Resources, and USDA-NRI grants 8937151-4487, 93-37302-9594, and 96-35302-3821. The authors acknowledge the efforts of the Pitch Canker Task Force to marshal support for pitch canker research. We also acknowledge helpful comments on earlier versions of this manuscript from B. Aegerter, D. Dekker, S. Kirkpatrick, W. Libby, D. Vogler, and two anonymous reviewers. We thank B. L. McFarland for technical assistance in the preparation of figures for this manuscript.

\section{Literature Cited}

1. Barrows-Broaddus, J., and Dwinell, L. D. 1985. Branch dieback and cone and seed infection caused by Fusarium moniliforme var. subglutinans in a loblolly pine seed orchard in South Carolina. Phytopathology 75:11041108.

2. Bonello, P., Gordon, T. R., and Storer, A. J. 2001. Systemic induced resistance in Monterey pine. For. Pathol. 31:1-8.

3. Bonello, P., McNee, W. R., Storer, A. J., Wood, D. L., and Gordon, T. R. 2001. The role of olfactory stimuli in the location of weakened hosts by twig-infesting Pityophthorus spp. Ecol. Entomol. 26:8-15.

4. Bright, D. E., and Stark, R. W. 1973. Bark and ambrosia beetles of California. Coleoptera: Scolytidae and Platypodidae. Bull. Calif. Insect Surv. 16

5. Britz, H., Coutinho, T. A., Wingfield, M. J., Marasas, W. F. O., Gordon, T. R., and Leslie, J. F. 1999. Fusarium subglutinans f. sp. pini represents a distinct mating population in the Gibberella fujikuroi species complex. Appl. Environ. Microbiol. 64:1198-1201.

6. Clark, S. L. 1998. The susceptibility of native California conifers to pitch canker and the association of the pathogen, Fusarium subglutinans f. sp. pini, with soil and seed. M.S. thesis. University of California, Davis

7. Correll, J. C., Gordon, T. R., and McCain, A. H. 1992. Genetic diversity in California and Florida populations of the pitch canker fungus Fusarium subglutinans f. sp. pini. Phytopathology 82:415-420.

8. Correll, J. C., Gordon, T. R., McCain, A. H., Fox, J. W., Koehler, C. S., Wood, D. L., and Schultz, M. E. 1991. Pitch canker disease in California: Pathogenicity, distribution, and canker development on Monterey pine (Pinus radiata). Plant Dis. 75:676-682.

9. Dallara, P. L. 1997. Studies on the distribution, interspecific relationships, host range, and chemical ecology of Pityophthorus spp. (Coleoptera:Scolytidae) and selected insectan associates, and their associations with Fusarium subglutinans $\mathrm{f}$. sp. pini in central coastal California. Ph.D. diss. University of California, Berkeley.

10. Dallara, P. L., Seybold, S. J., Meyer, H., Tolasch, T., Franke, W., and Wood, D. L. 2000. Semiochemicals from three species of Pityophthorus (Coleoptera:Scolytidae): Identification and field response. Can. Entomol. 132:889-906

11. Deghi, G. S., Huffman, T., and Culver, J. W. 1995. California's native Monterey pine populations: Potential for sustainability. Fremontia 23:14-23.

12. Desjardins, A. E., Plattner, R. D., and Gordon, T. R. 2000. Gibberella fujikuroi mating population A and Fusarium subglutinans from teosinte species and maize from Mexico and Central
America. Mycol. Res. 104:865-872.

13. Dwinell, L. D., Barrows-Broaddus, J. B., and Kuhlman, E. G. 1985. Pitch canker: A disease complex of southern pines. Plant Dis. 69:270276.

14. Fox, J. W., Wood, D. L., and Koehler, C. S. 1990. Distribution and abundance of engraver beetles (Scolytidae: Ips spp.) on Monterey pines infected with pitch canker. Can. Entomol. 122:1157-1166.

15. Fox, J. W., Wood, D. L., Koehler, C. S., and O'Keefe, S. T. 1991. Engraver beetles (Scolytidae: Ips spp.) as vectors of the pitch canker fungus, Fusarium subglutinans. Can. Entomol. 123:1355-1367.

16. Fransen, J. J., and Buisman, C. 1935. Infectieproven op verschillende ipensooten met behulp iepen spinktkevers. Tijdschr. Plantenziekten 41:221-239.

17. Gordon, T. R., Storer, A. J., and Okamoto, D. 1996. Population structure of the pitch canker pathogen, Fusarium subglutinans f. sp. pini, in California. Mycol. Res. 100:850-854.

18. Gordon, T. R., Storer, A. J., Okamoto, D., and Wood, D. L. 1998. Susceptibility of five landscape pines to pitch canker, caused by Fusarium subglutinans f. sp. pini. HortScience 33:868-871.

19. Gordon, T. R., Wikler, K. R., Clark, S. L., Okamoto, D., Storer, A. J., and Bonello, P. 1998. Resistance to pitch canker disease, caused by Fusarium subglutinans f. sp. pini, in Monterey pine (Pinus radiata). Plant Pathol. 47:706-711.

20. Griffin, J. R., and Critchfield, W. B. 1972 The Distribution of Forest Trees in California. U.S. Dep. Agric. For. Serv. Res. Pap. PSW-82.

21. Guerra-Santos, J. J. 1999. Pitch canker in Monterey pine in Mexico. Pages 58-61 in: Current and Potential Impacts of Pitch Canker in Radiata Pine. Proc. IMPACT Monterey Workshop, Monterey, CA. M. Devey, C. Matheson, and T. Gordon, eds. CSIRO, Australia.

22. Hepting, G. H. 1961. Pinus radiata susceptible to pitch canker. Plant Dis. Rep. 45:889-890.

23. Hepting, G. H., and Roth, E. R. 1946. Pitch canker, a new disease of some southern pines. J. For. 44:742-744.

24. Hoover, K., Wood, D. L., Fox, J. W., and Bros, W. E. 1995. Quantitative and seasonal association of the pitch canker fungus, Fusarium subglutinans f. sp. pini, with Conophthorus radiatae (Coleoptera: Scolytidae) and Ernobius punctulatus (Coleoptera: Anobiidae) which infest Pinus radiata. Can. Entomol. 127:79-91.

25. Hoover, K., Wood, D. L., Storer, A. J., Fox, J. W., and Bros, W. E. 1996. Transmission of the pitch canker fungus, Fusarium subglutinans $\mathrm{f}$ sp. pini, to Monterey pine, Pinus radiata, by cone- and twig-infesting beetles. Can. Entomol. 128:981-994.

26. Leach, J. G. 1940. Insect Transmission of Plant Disease. McGraw-Hill Book Co., New York.

27. Leslie, J. F. 1993. Fungal vegetative compatibility. Annu. Rev. Phytopathol. 31:127-150.

28. Libby, W. J., Bannister, M. H., and Linhart, Y. B. 1968. Pines of Cedros and Guadalupe Islands. J. For. 66(11):846-853.

29. Little, E. L., Jr. 1971. Atlas of United States Trees. Vol. 1. Conifers and Important Hardwoods. U.S. Dep. Agric. For. Serv. Misc. Publ. 1146

30. McCain, A. H., Koehler, C. S., and Tjosvold, S. A. 1987. Pitch canker threatens California pines. Calif. Agric. 41:22-23.

31. McDonald, M. J. 1994. Temperature: Effects on Fusarium subglutinans f. sp. pini infection on juvenile Pinus radiata (Monterey pine) and influence on growth of Fusarium subglutinans f. sp. pini isolates from Florida and 
California. M.S. thesis. San Jose State University, San Jose, CA.

32. Millar, C. I. 1998. Early evolution of pines. Pages 69-91 in: Ecology and Biogeography of Pinus. D. M. Richardson, ed. Cambridge University Press, Cambridge.

33. Morrell, J. J. 1995. Importation of unprocessed logs into North America: A review of pest mitigation procedures and their efficacy. For. Products J. 45(9):41-50.

34. Richardson, D. M., and Rundel, P. W. 1998. Pine ecology and biogeography - an introduction. Pages 3-46 in: Ecology and Biogeography of Pinus. D. M. Richardson, ed. Cambridge University Press, Cambridge.

35. Spencer, D., Eldridge, K., and Matheson, C. 1998. Conserving the natural genetic resources of Pinus radiata outside California and Mexico. Proceedings of a workshop held at Canberra, October 6, 1998. CSIRO Forestry and Forest Products, Canberra, Australia.

36. Storer, A. J., Bonello, P., Gordon, T. R., and Wood, D. L. 1999. Evidence of resistance to the pitch canker pathogen (Fusarium circinatum) in native stands of Monterey pine (Pinus radiata). For. Sci. 45(4):500-505.

37. Storer, A. J., Gordon, T. R., and Clark, S. L. 1998. Association of the pitch canker fungus,
Fusarium subglutinans f. sp. pini with Monterey pine seeds, and seedlings in California. Plant Pathol. 47:649-656.

38. Storer, A. J., Gordon, T. R., Wood, D. L., and Bonello, P. 1997. Current and future impacts of pitch canker disease of pines. J. For. 95:21-26.

39. Storer, A. J., Wood, D. L., and Gordon, T. R. 1999. Modification of co-evolved insect-plant interactions by an exotic plant pathogen. Ecol. Entomol. 24:238-243.

40. Storer, A. J., Wood, D. L., and Gordon, T. R. The epidemiology of pitch canker of Monterey pine in California. For. Sci. In press.

41. Storer, A. J., Wood, D. L., Gordon, T. R., and Libby, W. J. 2001. Native Monterey pine forest restoration in the presence of an exotic pathogen on the Monterey Peninsula. J. For. 99:14-18.

42. Storer, A. J., Wood, D. L., Wikler, K. R., and Gordon, T. R. 1998. Association between a native spittlebug (Homoptera:Cercopidae) on Monterey pine and an introduced tree pathogen which causes pitch canker disease. Can. Entomol. 130:783-792.

43. Swart, W. J., and Wingfield, M. J. 1991. Seasonal response of Pinus radiata in South Africa to artificial inoculation with Sphaeropsis sapinea. Plant Dis. 75:1031-1033.
44. Viljoen, A., and Wingfield, M. J. 1994. First report of Fusarium subglutinans f. sp. pini on pine seedlings in South Africa. Plant Dis. 78:309-312.

45. Wikler, K. R. 1999. Tracing the course of an introduced pathogen: Population biology of the causal agent of pitch canker, Fusarium circinatum, and epidemiology of pitch canker disease in a native stand of Pinus radiata. $\mathrm{Ph}$.D. diss. University of California, Berkeley.

46. Wikler, K., and Gordon, T. R. 2000. An initial assessment of genetic relationships among populations of Fusarium circinatum in different parts of the world. Can. J. Bot. 78:709717.

47. Wikler, K., Gordon, T. R., Clark, S. L., Wingfield, M. J., and Britz, H. 2000. Potential for outcrossing in an apparently asexual population of Fusarium circinatum, the causal agent of pitch canker. Mycologia 92:1085-1090.

48. Wingfield, M., Wingfield, B., Coutinho, T., Viljoen, A., Britz, H., and Steenkamp, E. 1999. Pitch canker: A South African perspective. Pages 62-69 in: Current and Potential Impacts of Pitch Canker in Radiata Pine. Proc. IMPACT Monterey Workshop, Monterey, CA. M. Devey, C. Matheson, and T. Gordon, eds. CSIRO, Australia.

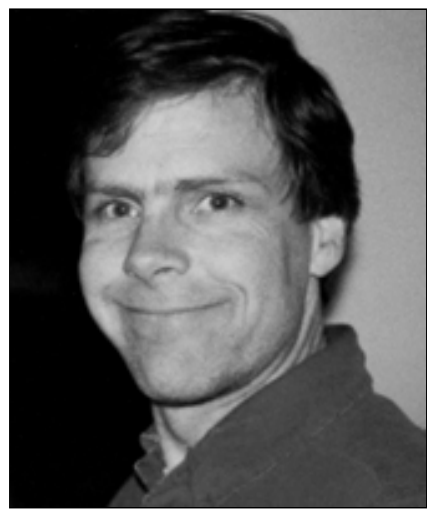

\section{T. R. Gordon}

Dr. Gordon is a professor in the Department of Plant Pathology at the University of California, Davis. His research interests are in the ecology and evolution of plant pathogenic fungi, fungal-insect-plant interactions, and management of plant diseases in agricultural and native ecosystems, with a primary emphasis on diseases caused by species of Fusarium. He has a longstanding collaborative project on pitch canker with co-authors D. L. Wood and A. J. Storer. He received his Ph.D. from U.C. Davis in 1981, where he continued as a postdoctoral researcher until joining the faculty in the plant pathology department at U.C. Berkeley in 1985. In 1996, he accepted his current position at U.C. Davis.

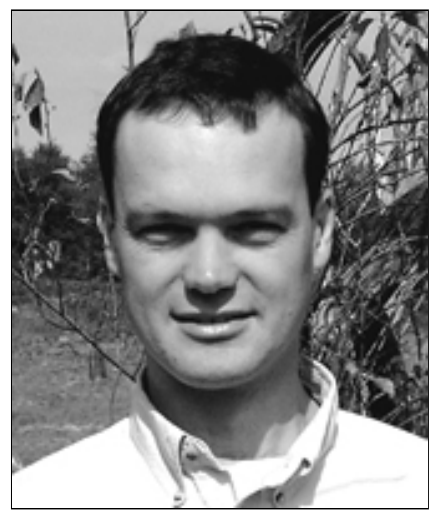

\section{A. J. Storer}

Dr. Storer is assistant professor of forest insect ecology in the School of Forestry and Wood Products at Michigan Technological University. His research interests are insect-fungus-plant interactions in forest ecosystems; impacts of exotic species on forest ecosystems; interactions among fire, insects, and disease in forests; and urban forest health. He has a B.A. in pure and applied biology, an M.A., and a D.Phil in forest entomology from the University of Oxford, England. During his graduate studies, he spent 6 months in Brussels, Belgium, on a Wiener-Anspach Foundation Fellowship. He has collaborated with T. R. Gordon and D. L. Wood since 1992 as a postdoctoral researcher and assistant research entomologist at the University of California at Berkeley, and in his current position in Michigan.

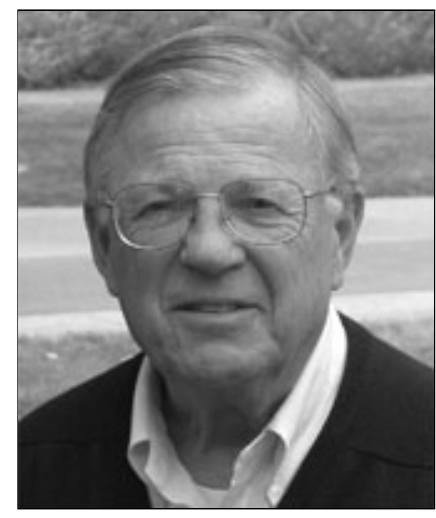

\section{L. Wood}

Dr. Wood is professor emeritus of entomology in the Division of Insect Biology and a professor of the graduate school at the University of California, Berkeley. His research interests include insect-fungus-plant interactions with emphasis on agents of tree predisposition to bark beetle infestation such as root diseases, co-evolved bluestain fungi vectored by bark beetles, and exotic pathogens in California's pine and oak forests. He also has investigated the chemical ecology of bark beetles, termites, and carpenter ants. He continues his stimulating and enjoyable collaboration with Professors Gordon and Storer as they investigate the pitch canker pathogen in California. $\mathrm{He}$ received his Ph.D. in entomology from the University of California at Berkeley and has pursued research and teaching at UCB since that time. 